\title{
FÁZOVÉ SLOŽENÍ STŘEDOVĚKÝCH STRUSEK PO TAVBĚ Pb-Ag RUD Z HUTNICKÉHO AREÁLU PLANDRY U JIHLAVY
}

\author{
Phase composition of Medieval slags after smelting of $\mathrm{Pb}-\mathrm{Ag}$ ores from the metallurgical \\ complex Plandry near Jihlava
}

\author{
Jaroslav Kapusta', Zdeněk Dolníček', Karel Malý \\ ${ }^{1}$ Katedra geologie PřF UP, 17. listopadu 1192/12, 77146 Olomouc; e-mail: jaroslav.kapusta@gmail.com \\ ${ }^{2}$ Muzeum Vysočiny Jihlava, Masarykovo nám. 55, 58601 Jihlava
}

(23-23 Jihlava)

Key words: Jihlava ore district, archaeometallurgy, slag

\begin{abstract}
Slags after silver smelting from the metallurgical site Plandry near Jihlava were examined in order to assess the conditions of smelting and composition of the charge. Samples were studied by a polarizing microscope in transmitted and reflected light and selected phases were analyzed using electron microprobe. Two different types of slag were specified on the basis of their phase composition. The first is made up of glass, olivine, and sulphides. In the second type, olivine and glass predominate and spinelide, K-Ba-feldspar, leucite, and sulphides are present in less quantity. Sulphides are present as droplets formed by the Cu-Fe-S matrix with inclusions of shandite, sphalerite, and an unknown $\mathrm{Cu}-\mathrm{Pb}$-S phase. Slag contains also relicts of unmelted quartz and chromspinel. The presence of $\mathrm{Fe}^{3+}$ in newly formed spinelide reflects at least partially oxic conditions during melting. The mesothermal type of ore with gangue formed by quartz, barite, and carbonate of the dolomite-ankerite series was probably processed. Low contents of lead in glass as well as low volume of $\mathrm{Pb}$-Ag-bearing sulphides reflect good yield of metals of interest ( $\mathrm{Pb}, \mathrm{Ag}$ ). Slags represent a potential environmental hazard due to relatively high contents of $\mathrm{Zn}$ (up to $6.6 \mathrm{wt}$. \% $\mathrm{ZnO}$ in the glass).
\end{abstract}

\section{Úvod}

Zájmová lokalita spadá do jihlavského rudního revíru. Ten je v nejužším slova smyslu chápán jako území o celkové rozloze okolo $63 \mathrm{~km}^{2}$ vymezené obcemi Zbornou, Kostelcem, Výskytnou, Rančírovem, Kosovem, Malým Beranovem a Bedřichovem (Malý 1999, Šamalová 2007). Žilná Pb-Zn-Ag mineralizace jihlavského rudního revíru je vázána na zlomové struktury $\mathrm{v}$ jednotvárné skupině moldanubika (Zajíček 1983). Na základě izotopového složení $\mathrm{S}$ a $\mathrm{O}$ a minerálních asociací je možné vyčlenit dva typy mineralizace, vysokoteplotní a mesotermální. Podstatnými složkami obou typů jsou sfalerit s galenitem, ke kterým přistupují pyrit $s$ arsenopyritem a v menším až akcesorickém množství chalkopyrit, pyrhotin, tetraedrit, freibergit, pyrargyrit a argentit. Žilovinou je křemen s karbonáty, u mineralizací vznikajících za středních až nižších teplot je př́ítomen $\mathrm{v}$ proměnlivém množství $\mathrm{i}$ baryt (Malý et al. 2008). Tetraedrit, pyrargyrit a freibergit jsou obvykle $\mathrm{v}$ rudě prítomny jen jako inkluze $\mathrm{v}$ galenitu (Malý 1999). Galenit je tak hlavním nositelem stříbra, ač samotné obsahy Ag v galenitu se pohybují v prvních stovkách ppm (Malý 2004). Zde je třeba však uvést, že se vychází ze současných nálezů z odvalů a tak se dá jen dohadovat, nakolik stříbrem bohatý byl galenit těžený v prvních etapách dolování.

Největší význam $\mathrm{v}$ této oblasti měla především starohorská dislokační zóna, na kterou byly vázány počátky těžby. Těžba zde začala přibližně v 30 . letech 13. stol. a intenzivně zde probíhala až do konce 13. stol. (Vosáhlo 2004). Druhá etapa, která je zasazena přibližně do období mezi 15.-17. stol. byla zaměřena spíše na ověřování a př́ípadně obnovu starých důlních děl nebo byla spojena se snahou nalézt pokračování dosud nedotčených mineralizovaných struktur. Poslední významná etapa zaměřená spíše na prozkoumání a evidenci starých děl proběhla v 18. stol. (Vosáhlo 1995).
Celý proces extrakce stř́bra $\mathrm{z}$ rudy byl složen $\mathrm{z}$ různého množství úkonů, které se liší podle typu zpracovávané rudy. Velmi zjednodušeně se dá shrnout do čtyř hlavních bodů (Ströbele et al. 2010, Vaněk - Velebil 2007):
a) mechanická úprava,
b) pražení,
c) redukční tavení,
d) kupelace.

Výsledkem redukčního tavení byla slitina označovaná jako hutní olovo, do kterého se vázalo stř́bro z rudy. $\mathrm{V}$ prípadě chudých rud se tato slitina vracela do procesu redukčního tavení a obohacovala se tak stř́ibrem. Při oddělování stř́ibra $z$ hutního olova při tzv. kupelaci byla tato slitina roztavena a na její povrch byl vháněn vzduch, olovo oxidovalo na $\mathrm{PbO}$, ten byl z povrchu odstraňován. Výsledkem bylo stř́bro různé ryzosti, které se dále upravovalo. Největši objemy strusky tedy vznikaly ve fázi redukčního tavení (Vaněk - Velebil 2007).

Složení strusky se dá obvykle poměrně dobře aproximovat prostřednictvím $\mathrm{SiO}_{2}, \mathrm{FeO}, \mathrm{CaO}$ a $\mathrm{Al}_{2} \mathrm{O}_{3}$, menší jsou obsahy $\mathrm{MgO}$ a $\mathrm{K}_{2} \mathrm{O}$. Z mineralogického hlediska jsou ve struskách nejběžnější vysokoteplotní Ca-Fe silikáty, v menším množství oxidy a obvykle ve formě kapek bývají zachyceny sulfidy a kovové slitiny. Nedílnou součástí strusek je i sklo a neroztavené relikty žiloviny. Mineralogické složení strusek je pak odrazem složení rudy, př́měsí, dosažené teploty a rychlostí chlazení (Ettler et al. 2001). Navíc, jak dokládají nálezy např́íklad i ze starohorského pásma, byla samotná struska po tavbě stř́bra často přidávána do nové vsázky a tím recyklována $\mathrm{v}$ následných tavbách (Malý 2004). 


\section{Metodika a výsledky}

Hutnický areál Plandry se nacházel v levém břehu hlavního meandru Bělokamenského potoka na GPS souřadnicích $49^{\circ} 25^{`} 6,060^{\prime \prime} \mathrm{N}$ a $15^{\circ} 31^{\prime} 42,841^{\prime \prime} \mathrm{E}$. Velice podrobně se popisem lokality s ohledem na archeologii zabývá Šamalová (2007). Na základě studia archeologických nálezů zařazuje Šamalová (2007) působnost hutnického areálu do vrcholné éry jihlavského hornictví na přelomu 13.-14. stol. Vzorky k podrobnému studiu byly odebírány z koryta Bělokamenského potoka a $\mathrm{z}$ mikrosondáže o rozměru $1 \times 1,5 \mathrm{~m}$ a hloubce $1 \mathrm{~m}$. V sondě tvoří strusky horizont o celkové mocnosti až $60 \mathrm{~cm}$, překrytý $20 \mathrm{~cm}$ mocnou vrstvou půdy. Strusky představují i podstatnou součást sedimentu současného koryta potoka. Podrobněji byl materiál studován polarizačním mikroskopem, vybrané fáze byly analyzovány metodou WDX na mikrosondě CAMECA SX100 v Brně na společném pracovišti Přírodovědecké fakulty Masarykovy univerzity a České geologické služby. Bodové analýzy olivínů a skla byly provedeny za následujících podmínek: urychlovací napětí $15 \mathrm{keV}$, proud $10 \mathrm{nA}$ a průměr svazku $3 \mu \mathrm{m}$. Živce a leucit byly analyzovány za stejných napětových a proudových podmínek, jen průměr svazku byl $2 \mu \mathrm{m}$. Sulfidy byly analyzovány při urychlovacím napětí $20 \mathrm{keV}$, proudu $25 \mathrm{nA}$, průměru svazku $<1 \mu \mathrm{m}$ a spinelidy při urychlovacím napětí $15 \mathrm{keV}$ proudu $20 \mathrm{nA}$ a průměru svazku $<1 \mu \mathrm{m}$.

Rozměr odebraných vzorků se pohybuje od jednotek $\mathrm{cm}$ až po $15 \mathrm{~cm}$. Tvar je vždy nepravidelný, stejně jako lom,
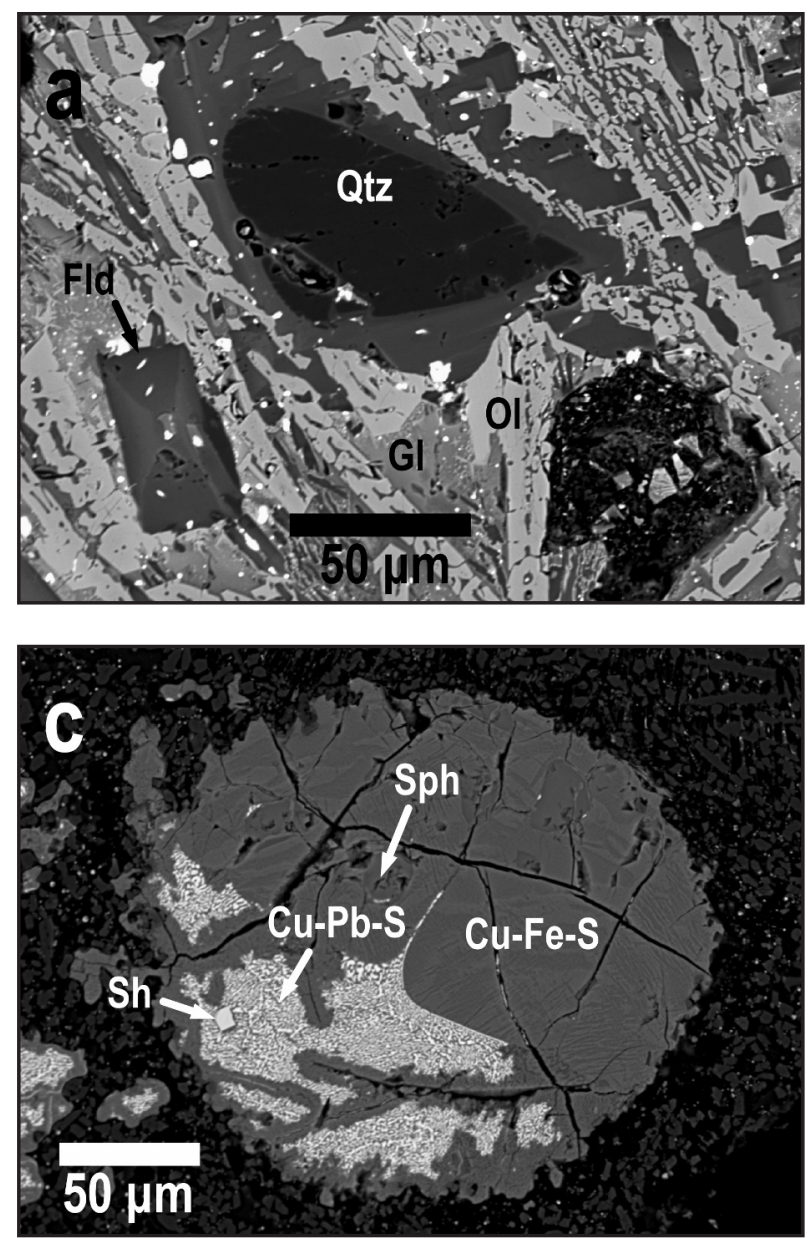
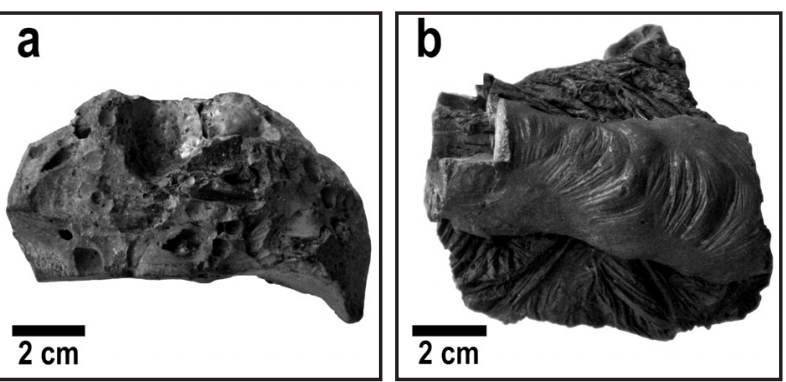

Obr. 1: Odebrané vzorky strusky z lokality Plandry: a - světle zbarvená varieta; b - povrch odrážející stopy po tečení.

Fig. 1: Samples of slag from the site Plandry: a - light-coloured variety; $\mathrm{b}$ - surface reflecting the flow.

lomné plochy jsou matné nebo skelně lesklé. Nejběžnější jsou ostrohranné úlomky, ale podařilo se najít i celotvary. Barva je proměnlivá, šedá (obr. 1a) až téměř černá. Na povrchu některých vzorků jsou pozorovatelné stopy po tečení připomínající povrch provazových láv (obr. 1b). Často jsou ve strusce zachyceny relikty žiloviny v podobě až několik milimetrů velkých, rozpraskaných, izometrických zrn křemene, případně kapky tvořené sulfidy. Běžné jsou drobné póry i několik centimetrů velké dutiny. Póry mají nepravidelný i přibližně sférický tvar a jejich distribuce je nahodilá.

Složení strusek zjištěné na základě studia pomocí polarizačního mikroskopu v procházejícím a odraženém světle, podpořeného analýzami na mikrosondě, je násle-

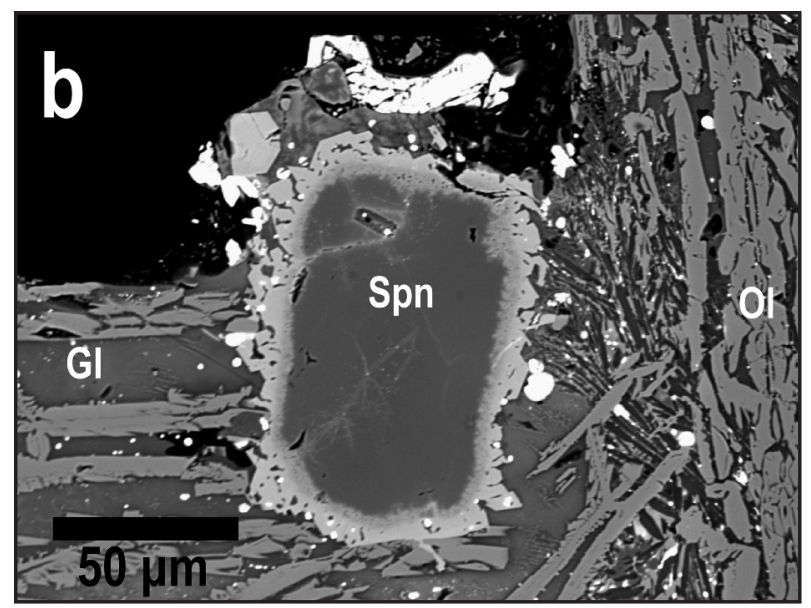

Obr. 2: Snímky v odražených elektronech: a - K-Ba živec s přesypátkovou strukturou (Fld), oválný křemen (Qtz), olivín (Ol), sklo (Gl) a sulfidické fáze (bílé); b - zonální zrno spinelidu (Spn), olivín (Ol), sklo (Gl) a kapky sulfidických fází (bílé); c - sulfidická kapka tvořená $\mathrm{Cu}-\mathrm{Fe}-\mathrm{S}$ fází (lišty + matrice, popsáno v textu) s oválnými inkluzemi sfaleritu (Sph), izometrickým automorfním zrnem shanditu ( $\mathrm{Sh}$ ) a $\mathrm{Cu}-\mathrm{Pb}$-S fáze jako drobné bílé červíkovité inkluze. Foto P. Gadas.

Fig. 2: The BSE images: a - K-Ba feldspar with sandglass structure $(\mathrm{Fl})$, oval quartz $(\mathrm{Qtz})$, olivine $(\mathrm{Ol})$, glass $(\mathrm{Gl})$ and sulphide phases (white); b - zonal grain of spinelide (Spn), olivine (Ol), glass (Gl) and droplets of sulphide phases (white); $\mathrm{c}$ - a sulphide droplet formed by $\mathrm{Cu}-\mathrm{Fe}-\mathrm{S}$ phase (strips + matrix, described in the text) with oval inclusions of sphalerite (Sph), isometric euhedral grain of shandite $(\mathrm{Sh})$ and $\mathrm{Cu}-\mathrm{Pb}-\mathrm{S}$ phase as subtle white wormslike inclusions. Photo P. Gadas. 
dující: olivín, spinelidy, sklo, sulfidy, živec a leucit. Celkem byly identifikovány dva typy asociací (sulfidy jsou běžné v obou typech):
a) olivín, sklo,
b) spinelid, olivín, živec, leucit, sklo.

Olivín představuje nejčetnější krystalickou fázi strusek, zároveň je nejproměnlivější ve své morfologii a to i v rámci jednoho vzorku. Nejtypičtější jsou olivíny ve formě skeletálních jehlicovitých krystalů, ty jsou jen několik desetin mm široké, ale až několik milimetrů dlouhé. V asociaci b) se nachází i zcela automorfně omezená, přibližně izometrická zrna. Interferenční barvy odpovídají II. řádu. Analytická data (tab. 1) ukazují, že na složení olivínu se významnou měrou podílí fayalitová a forsteritová komponenta. Př́tomnost tak vysokých obsahů forsteritové složky (5,3-9,2 hm. \% MgO, odpovídající 13-22 mol. \% forsteritové molekuly) není v těchto struskách běžná. Neobvyklé

\begin{tabular}{|c|c|c|c|c|c|c|c|c|c|}
\hline \multirow[b]{3}{*}{$\mathrm{SO}_{3}$} & \multirow{2}{*}{\multicolumn{2}{|c|}{ olivín }} & \multicolumn{2}{|c|}{ spinelid } & \multirow{2}{*}{\multicolumn{2}{|c|}{ živec }} & \multirow{3}{*}{ leucit } & \multirow{2}{*}{\multicolumn{2}{|c|}{ sklo }} \\
\hline & & & stř̌ed & okraj & & & & & \\
\hline & & & & & & & & 0,55 & 0,84 \\
\hline $\mathbf{P}_{2} \mathbf{O}_{5}$ & 0,00 & 0,07 & & & & & & 0,74 & 0,72 \\
\hline $\mathrm{SiO}_{2}$ & 31,64 & 31,56 & 0,02 & 0,49 & 58,38 & 55,02 & 57,07 & 47,88 & 44,37 \\
\hline $\mathrm{TiO}_{2}$ & 0,03 & 0,06 & 0,35 & 4,48 & 0,10 & 0,14 & 0,01 & 0,81 & 0,58 \\
\hline $\mathrm{Al}_{2} \mathrm{O}_{3}$ & 0,04 & 0,33 & 29,93 & 4,26 & 19,67 & 21,13 & 22,15 & 11,97 & 11,96 \\
\hline $\mathrm{Cr}_{2} \mathrm{O}_{3}$ & & & 34,98 & 0,31 & 0,02 & 0,01 & 0,00 & & \\
\hline $\mathrm{V}_{2} \mathrm{O}_{3}$ & & & 0,61 & 0,21 & 0,00 & 0,02 & 0,02 & & \\
\hline $\mathrm{FeO}^{\text {tot. }}$ & 49,78 & 51,40 & 22,47 & 75,05 & 0,86 & 1,04 & 0,76 & 14,11 & 14,76 \\
\hline $\mathrm{MnO}$ & 3,45 & 3,43 & 0,26 & 0,79 & 0,00 & 0,05 & 0,04 & 0,83 & 0,98 \\
\hline $\mathrm{MgO}$ & 9,15 & 5,32 & 10,88 & 0,31 & 0,02 & 0,00 & 0,01 & 0,22 & 0,14 \\
\hline $\mathrm{CaO}$ & 0,45 & 0,68 & 0,02 & 0,10 & 0,21 & 1,75 & 0,00 & 6,97 & 8,88 \\
\hline $\mathrm{NiO}$ & & & 0,20 & 0,02 & & & & & \\
\hline $\mathrm{ZnO}$ & 5,72 & 6,37 & 0,21 & 6,55 & 0,37 & 0,47 & 0,08 & 5,07 & 6,55 \\
\hline $\mathrm{PbO}$ & 0,00 & 0,00 & & & & & & 1,92 & 3,29 \\
\hline $\mathrm{BaO}$ & & & & & 7,80 & 8,40 & 0,80 & & \\
\hline SrO & & & & & 0,13 & 0,25 & 0,00 & & \\
\hline $\mathrm{Na}_{2} \mathrm{O}$ & 0,16 & 0,21 & & & 1,00 & 1,17 & 0,36 & 0,90 & 1,08 \\
\hline $\mathrm{K}_{2} \mathrm{O}$ & 0,04 & 0,24 & & & 11,45 & 9,89 & 19,26 & 3,99 & 2,81 \\
\hline celkem & 100,46 & 99,67 & 99,92 & 92,56 & 100,01 & 99,35 & 100,56 & 95,95 & 96,96 \\
\hline Si & 1,00 & 1,02 & & 0,02 & 2,84 & 2,72 & 2,05 & & \\
\hline $\mathrm{Ti}$ & & & 0,01 & 0,14 & & 0,01 & & & \\
\hline Al & & 0,01 & 1,07 & 0,20 & 1,13 & 1,23 & 0,94 & & \\
\hline $\mathrm{Cr}$ & & & 0,84 & 0,01 & & & & & \\
\hline $\mathrm{Fe}^{3+}$ & & & 0,06 & 1,47 & & & & & \\
\hline $\mathrm{Fe}^{2+}$ & 1,32 & 1,39 & 0,50 & 0,91 & 0,03 & 0,04 & 0,02 & & \\
\hline Mn & 0,09 & 0,09 & 0,01 & 0,03 & & & & & \\
\hline $\mathrm{Mg}$ & 0,43 & 0,26 & 0,49 & 0,02 & & & & & \\
\hline $\mathrm{Ca}$ & 0,02 & 0,02 & 0,00 & 0,00 & 0,01 & 0,09 & 0,00 & & \\
\hline $\mathrm{Zn}$ & 0,13 & 0,15 & & 0,20 & 0,01 & 0,02 & & & \\
\hline $\mathrm{Ba}$ & & & & & 0,15 & 0,16 & 0,01 & & \\
\hline $\mathrm{Na}$ & & & & & 0,09 & 0,11 & 0,02 & & \\
\hline $\mathrm{K}$ & & & & & 0,71 & 0,62 & 0,88 & & \\
\hline celkem & 2,99 & 2,96 & 3,00 & 3,00 & 4,98 & 5,02 & 3,92 & & \\
\hline
\end{tabular}

Tab. 1: Reprezentativní výsledky WDX analýz olivínů, spinelidu, živce, leucitu a skla (hm. \%). Empirické vzorce olivínů přepočteny na bázi 4 kyslíků, živec na 8 kyslíků a leucit na 6 kyslíků. Spinelidy byly přepočteny na 4 kyslíky a 3 kationty na vzorcovou jednotku. Tab. 1: Representative WDX analyses of olivine, spinelide, feldspar, leucite and glass (wt. \%). The empirical formulae of olivine, feldspar and leucite are recalculated on basis of 4,8 , and 6 atoms of oxygen, respectively. Spinelides were recalculated on basis of 4 oxygens and 3 cations per formula unit. jsou i nízké obsahy Ca (maximálně 0,7 hm. \% CaO); tak nízké obsahy nejsou ani v relativně na $\mathrm{CaO}$ chudých raně krystalizujících olivínech popisovaných ze strusek z příbramského rudního revíru (Ettler et al. 2001). Zajímavé jsou i zvýšené obsahy Zn (5,7-6,3 hmot. \% ZnO). Z výsledků WDX analýz byla potvrzena i přítomnost živce a leucitu (obr. 2a). Živec tvoří automorfní přibližně izometrická zrna, která někdy mají na fotografiích z odražených elektronů pozorovatelnou přesýpátkovou strukturu (obr. 2a). Z príměsí obsahuje zvýšené množství $\mathrm{Fe}(0,9-1,0 \mathrm{hm}$. \% $\mathrm{FeO}), \mathrm{Zn}(0,4-0,5$ hm. \% ZnO), Sr (0,1-0,3 hm. \% SrO) a $\mathrm{Ba}(9,9-11,4 \mathrm{hm}$. \% $\mathrm{BaO})$. Leucit má podobu oválných zrn. Obsahuje příměs $\mathrm{Ba}(0,8 \mathrm{hm}$. \% BaO), Fe (0,8 hm. \% $\mathrm{FeO})$ a $\mathrm{Na}\left(0,4\right.$ hm. \% $\left.\mathrm{Na}_{2} \mathrm{O}\right)$.

Spinelidy představují jedinou potvrzenou oxidickou fázi ve struskách. Předmětem WDX analýzy bylo izometrické zrno, které na snímku z odražených elektronů vykazuje zonálnost (obr. 2b), ta se projevuje tmavším oválným jádrem a světlejším nepravidelným nárůstem na okraji zrna. Chemické složení (tab. 1) nasvědčuje tomu, že jádro je tvořeno dominantně spinelidem řady chromit-spinel (49 mol. \% spinel, $42 \mathrm{~mol}$. \% chromit, 3 mol. \% hercynit, 3 mol. \% magnetit, $1 \mathrm{~mol}$ \% ulvöspinel a $1 \mathrm{~mol}$. \% galaxit). Složení okraje zrna je komplexnější a výrazně odlišné od chemismu jádra, zejména pokud jde o obsahy $\mathrm{Fe}, \mathrm{Mg}, \mathrm{Cr}, \mathrm{Ti}$ a $\mathrm{Zn}$. Vyjádřeno koncovými členy je složení okraje spinelidu následující: 63 mol. \% magnetit, 14 mol. \% ulvöspinel, $15 \mathrm{~mol}$ \% franklinit, 5 mol. \% gahnit, 3 mol. \% galaxit a 2 mol. \% spinel.

Sklo je př́ítomno v proměnlivém množství ve všech typech studovaných strusek. Tvoří výplň mezi jednotlivými krystalickými fázemi. Výjimkou nejsou ani vzorky tvořené téměř výhradně sklovitou hmotou s pozorovatelnou fluidální mikrotexturou. Barva skla v PPL je zelenožlutá až zelenohnědá, v XPL je někdy pozorovatelná částečná devitrifikace, která se projevuje anizotropií. Z výsledků WDX analýz je patrné, že $90 \%$ hmoty skla představuje suma sedmi oxidů: $44,4-47,9 \mathrm{hm}$. $\% \mathrm{SiO}_{2}$, 14,1-14,8 hm. \% FeO, 12,0 hm. \% $\mathrm{Al}_{2} \mathrm{O}_{3}, 7,0-8,9$ hm. \% CaO, 5,1-6,6 $\mathrm{hm}$. \% $\mathrm{ZnO}, 2,8-4,0 \mathrm{hm}$. \% $\mathrm{K}_{2} \mathrm{O}$ a 1,9-3,3 hm. \% PbO.

Při studiu v odraženém světle byla podrobněji věnována pozornost také až 0,2 mm velkým sulfidickým kapkám (obr. 2c). Hlavní matrice kapek je tvořena $\mathrm{Cu}-\mathrm{Fe}-\mathrm{S}$ fází. $\mathrm{V}$ matrici jsou uloženy drobné hypautomorfně 


\begin{tabular}{|l|c|c|c|c|}
\hline \multirow{2}{*}{} & \multirow{2}{*}{ shandit } & \multicolumn{2}{|c|}{ Cu-Fe-S } & \multirow{2}{*}{ sfalerit } \\
\cline { 3 - 4 } & & lišty & matrice & \\
\hline $\mathbf{P b}$ & 62,73 & 0,16 & 0,05 & \\
\hline $\mathbf{C u}$ & 1,86 & 55,27 & 60,91 & 1,55 \\
\hline $\mathbf{F e}$ & 0,48 & 14,15 & 11,15 & 11,12 \\
\hline $\mathbf{Z n}$ & 0,05 & 0,32 & 0,13 & 53,06 \\
\hline $\mathbf{C o}$ & 0,02 & 0,01 & 0,00 & 0,02 \\
\hline $\mathbf{M n}$ & 0,00 & 0,01 & 0,00 & 0,20 \\
\hline Sn & 0,06 & 0,00 & 0,00 & \\
\hline $\mathbf{C d}$ & 0,00 & 0,01 & 0,00 & 0,01 \\
\hline $\mathbf{A g}$ & 0,00 & 0,29 & 0,30 & \\
\hline $\mathbf{N i}$ & 25,69 & 0,00 & 0,00 & 0,01 \\
\hline Se & 0,00 & 0,04 & 0,00 & \\
\hline Sb & 0,00 & 0,03 & 0,03 & \\
\hline As & & & & 0,08 \\
\hline S & 9,99 & 30,30 & 28,35 & 34,25 \\
\hline celkem & 100,89 & 100,60 & 100,92 & 100,30 \\
\hline
\end{tabular}

Tab. 2: Výsledky WDX analýz sulfidů (hm. \%).

Tab. 2: Results of WDX analyses of sulphides (wt. \%).

omezené lišty složení podobného matrici, ale s nižšími obsahy $\mathrm{Cu}$ a vyššími Fe (viz tab. 2). V odraženém světle mají lišty béžovou a matrice hnědošedou barvu. Rozdíl je patrný i v BSE. Součástí kapky jsou i přibližně oválné inkluze sfaleritu, ten je také jediným nositelem zinku mezi sulfidickými fázemi. Obsahuje príměs Fe $(11,1 \mathrm{hm}$. \%) a Cu (1,6 hm. \%). Cu-Fe-S fáze jsou jediné sulfidické fáze, u kterých byla zjištěna přítomnost $\mathrm{Ag}$ (max. $0,30 \mathrm{hm} . \% \mathrm{Ag}$ ). $\mathrm{S} \mathrm{Cu}-\mathrm{Fe}-\mathrm{S}$ fází lokálně vytvárí eutektické srůsty $\mathrm{Cu}-\mathrm{Pb}-\mathrm{S}$ fáze (obr. 2c), jejíž jednotlivá individua jsou však př́liš malá pro provedení kvantitativní analýzy. Ojediněle bylo $\mathrm{v}$ dané asociaci zjištěno i izometrické automorfně omezené zrno Pb-Ni-S fáze stechiometricky odpovídající shanditu (obr. 2c), mající v odraženém světle stříbrnou barvu s nádechem do žluté. Kromě hlavních komponent obsahuje príměsi $\mathrm{Cu}(1,9 \mathrm{hm} . \%)$ a $\mathrm{Fe}(0,5 \mathrm{hm}$. \%). V odraženém světle je po obvodu celé kapky vidět jen několik $\mu \mathrm{m}$ mocný, sytě modře zbarvený a blíže neanalyzovaný lem tvořený pravděpodobně covellínem. Součástí strusek jsou i izometrická, oválná a silně rozpraskaná zrna křemene.

\section{Diskuze a závěr}

Morfologie olivínu může být podle Donaldsona (1976) přibližným ukazatelem rychlosti tuhnutí taveniny. $\mathrm{V}$ prrípadě asociace a) mohla být rychlost ochlazování i větší než $1000^{\circ} \mathrm{C} / \mathrm{h}$, tuto možnost podporuje i absence dalších silikátů stejně jako dendritické krystaly peř́ččkovitě rozvětveného olivínu. $\mathrm{V}$ př́padě asociace $\mathrm{b}$ ) se teplota strusky snižovala přibližně rychlostí $60^{\circ} \mathrm{C} / \mathrm{h}$ a v některých partiích struska nechladla rychleji než $7^{\circ} \mathrm{C} / \mathrm{h}$ (izometrická automorfní zrna, téměř absence skla). Baryt byl většinou ze vsázky velice pečlivě odstraňován, jak ukazuje př́tomnost barytového štěrku ve Starých Horách (Malý 2004), ale zvýšené obsahy Ba v živcích (9,9-11,4hm. \% BaO) a v leucitu $(0,8 \mathrm{hm}$. \% $\mathrm{BaO})$ lze chápat jako potvrzení jeho př́tomnosti a dá se proto předpokládat, že na studované lokalitě byl zpracováván mesotermální typ rud.
Přítomnost spinelidů s trojmocným železem ve struktuře odráží alespoň částečně oxidické podmínky v průběhu tavby (Manasse - Mellini 2002). Chromem obohacené jádro snad představuje relikt, který odolal tavení a poskytl tak krystalizační základ pro tvorbu lemu odlišného chemického složení. Absence vyšších obsahů Sb ve formě slitin nebo příměsí v sulfidech poukazuje bud' na pečlivé pražení rudy nebo absenci většího množství minerálů stř́bra jako je freibergit, tetraedrit nebo pyrargyrit ve zpracovávaných rudách. Zajímavá je i přítomnost shanditu, protože minerál s podstatným obsahem Ni, který by byl součástí rudy, není v jihlavském rudním revíru popisován (Malý 1999). Dá se předpokládat, že vstupní ruda byla na karbonáty chudá nebo byly karbonáty $z$ rudy odstraňovány $\mathrm{v}$ prrípravných fázích a zároveň nebylo př̀idáváno větší množství tavidel na bázi $\mathrm{CaO}$, jak potvrzují jeho nízké obsahy v olivínech, ale především skle (7,0-8,9 hm. \% CaO) a absence na $\mathrm{Ca}$ bohatších silikátů jako melilit či klinopyroxeny, jinde běžných (např. Manasse Mellini 2002). Z přítomnosti Ca a Mg se dá předpokládat, že vsázka obsahovala alespoň malé množství karbonátů dolomit-ankeritové řady. Olovo je ve struskách vedle sulfidické fáze, která představuje jen zlomek z celkového objemu, koncentrováno především ve skle, kde dosahuje hodnot až 3,3 hm. \%. Obsahy olova ve skelné fázi strusek z Plander jsou v porovnání s podobným materiálem ze Starých Hor vyšší (Hrubý et al. 2007), ale i tak společně se zanedbatelným množstvím Ag poukazují na poměrně dobře zvládnutou technologii hutnění, což se nedá říci např́íklad o struskách př́ibramských, které obsahují ve skle až 48,9 hm. \% PbO (Ettler et al. 2009).

Jak ukazuje např. práce Ettlera et al. (2001), objasnění teplotních podmínek panujících při tavbě z analýz skla prostřednictvím ternárního diagramu $\mathrm{SiO}_{2}-\mathrm{FeO}-\mathrm{CaO}$ používaného pro recentní strusky naráží na zásadní problém, kterým je nadhodnocení teplot. Zmíněná trojice oxido̊ celkem reprezentuje pouze $68,0-69,4 \%$ hmoty sklovitých strusek, z čehož je patrné komplexnější složení a pro relevantní určení teploty by bylo nutné uvažovat více komponent.

Přítomnost Zn dokazuje, že snahou tehdejších hutníků nebylo odstranit ze vsázky sfalerit. Zinek se sice již při teplotách okolo $900{ }^{\circ} \mathrm{C}$ vypařuje (Vaněk - Velebil 2007), ale i tak jsou jeho obsahy v raně krystalických fázích, stejně jako ve skle, relativně vysoké (až $6,6 \mathrm{hm}$. \% $\mathrm{ZnO}$ ve skle). Jako největší environmentální riziko je možné chápat $\mathrm{Zn}$ ve skle, nebot sklo podléhá zvětrávacím procesům nejrychleji a na rozdíl od olova zinek není fixován v navětralé části strusky (Ettler et al. 2001).

\section{Poděkování}

Autoři děkují P. Gadasovi (MU Brno) za asistenci při práci na mikrosondè.

Práce byla podpořena projektem IGA UP PrF_2012_004. 


\section{Literatura}

Donaldson, C. H. (1976): An experimental investigation of olivine morphology. - Contributions to Mineralogy and Petrology, $57,187-95$

Ettler, V. - Legendre, O. - Bodénan, F. - Touray, J. C. (2001): Primary phases and natural weathering of old lead-zinc pyrometallurgical slag from Př́ibram, Czech Republic. - Canadian Mineralogist, 39, 873-88.

Ettler, V. - Červinka, R. - Johan, Z. (2009): Mineralogy of medieval slags from lead and silver smelting (Bohutín, Prríbram district, Czech Republic): Towards estimation of historical smelting conditions. - Archaeometry, 51, 6, 987-1 007.

Hrubý, P. - Hejhal, P. - Malý, K. (2007): Těžba a úprava rud na jihlavských Starých Horách ve 13. století (Montánní archeologický výzkum a aplikace př́rodovědných analýz). - Stř́ibrná Jihlava 2007, 238-269.

Malý, K. (1999): Jihlava ore region - geology and mineralogy. - Silver-mining and coinage of Jihlava (Iglau), 16-29.

Malý, K. (2004): Mineralogické zhodnocení starohorských nálezů. - Stř́ibrná Jihlava 2004, 62.

Malý, K. - Dobeš, P. - Fojt, B. (2008): Stable isotope and fluid inclusion study of polymetallic mineralization in Jihlava Ore District (Czech Republic). - Mineralogia - Special Papers, 32, 111-112.

Manasse, A. - Mellini, M. (2002): Chemical and textural characterization of medieval slags from the Massa Marittima smelting sites (Tuscany, Italy). - Journal of Cultural Heritage, 3, 187-98.

Ströbele, F. - Wenzel, T. - Kronz, A. (2010): Mineralogical and geochemical characterization of high-medieval lead-silver smelting slags from Wiesloch near Heidelberg (Germany) - an approach to proces reconstruction. - Archaeological and Anthropological Sciences, 2, 191-215.

Šamalová, E. (2007): Zaniklý středověký hutnický areál Plandry u Jihlavy. - Stř́ibrná Jihlava 2007, 228-237.

Vaněk, V. - Velebil, D. (2007): Staré hutnictví stř́íbra. - Stř́íbrná Jihlava 2007, 188-205.

Vosáhlo, J. (1995): Metody vyhledávání a průzkumu stř́ibrorudných ložisek v rozmezí 13. až 18. století (se zřetelem k Jihlavskému rudnímu revíru). - Stř́ibrná Jihlava 1995, 29-43.

Vosáhlo, J. (2004): Hornická činnost na starohorské dislokační zóně z pohledu historických pramenů. - Stř́ibrná Jihlava 2004, 22-32.

Zajíček, P. (1983): Ocenění zásob Ag v jihlavském rudním revíru. - Časopis pro mineralogii a geologii, 28, 197-207. 